\title{
Turist Rehberi Akademisyenlerin Bilimsel Yayınlarının Veri Görselleştirme Tekniği ile Bibliyometrik Analizi
}

\author{
Arş. Gör. Ali KABAKULAK \\ Afyon Kocatepe Üniversitesi, Turizm Fakültesi \\ alikabakulak@aku.edu.tr \\ https://orcid.org/0000-0001-9256-8557 \\ DOI: https://doi.org/10.37847/tdtad.816627 \\ Makale Gönderim Tarihi: 26.10.2020
}

\author{
Arş. Gör. Mehmet BOYRAZ \\ Afyon Kocatepe Üniversitesi, Turizm Fakültesi \\ mboyraz@aku.edu.tr \\ https://orcid.org/0000-0001-6755-1999
}

Makale Türü: Araştırma Makalesi

Makale Kabul Tarihi: 19.11.2020

\section{Özet}

$\mathrm{Bu}$ araştırmanın amacı, turist rehberi akademisyenlerin yayınlarının veri görselleştirme tekniği ile bibliyometrik açıdan değerlendirilmesidir. Araştırmanın evrenini Türkiye'de turizm/turist rehberliği bölümlerinde görev yapan çalışma kartına sahip turist rehberi akademisyenlerin yayınları oluşturmaktadır. Araştırma verilerinin toplanmasında dokuman-arşiv tarama yöntemiyle üniversitelerin web siteleri, akademik veri bilgi sistemleri ve YÖK akademik veri tabanı taranmıştır. Veriler 01-29 Şubat 2020 tarihleri arasında toplanmıştır. Yayınların içeriklerine ve kapsamlarına ilişkin değerlendirmeler ise çalışma başlıkları üzerinde gerçekleştirilen veri görselleştirme analizi ile yapılmıştır. Rehber akademisyenlerin demografik bilgileri ve çalışma kartlarının nitelikleri ile yayınların niteliklerine ilişkin tanımlayıcı veriler betimsel analiz (yüzde ve sıklık analizi, aritmetik ortalama) ile çapraz tablolar halinde incelenmiştir. Yayınların içeriklerine ve kapsamlarına ilişkin değerlendirmeler ise çalışma başlıkları üzerinde gerçekleştirilen veri görselleştirme analizi ile yapılmıştır. Verilerin görselleştirilmesinde interaktif bir yazılım olan Tableau kullanılmıştır. Araştırma kapsamında turist rehberi akademisyenlerin toplamda 1415 yayın ürettikleri; bu yayınlar arasında en fazla yayının 626 ile bildiri (tebliğ) ve 488 ile makale türünde yapıldığı, bunu 279 kitap bölümünün ve 22 kitabın takip ettiği belirlenmiştir. Yayın dili açısından ağırlıklı olarak Türkçe yayınlar öne çıkmıştır.

Anahtar Kelimeler: Turizm Araştırmaları, Turist Rehberliği, Rehber Akademisyen, Bibliyometrik Analiz, Tableau.

\section{Bibliometric Analysis of Scientific Publications of Tourist Guide Academics with Data Visualization Technique}

\begin{abstract}
The aim of this study is to evaluate the publications of tourist guide academicians in terms of bibliometric using data visualization technique. The population of the study constitute of tourist guides academician publications who have a license. In the collection of research data, universities' websites, academic data information systems and YÖK academic database were scanned by document-archive scanning method. The data were collected between 01-29 February 2020. The evaluations regarding the content and scope of the publications were made with the data visualization analysis performed on the study titles. The demographic information of the guiding academicians and the qualifications of the license and the descriptive data regarding the qualifications of the publications were analyzed in cross tables with descriptive analysis (percentage and frequency analysis, arithmetic mean). The evaluations regarding the content and scope of the publications were made with the data visualization analysis performed on the study titles. Tableau, an interactive software, was used for visualizing the data. Within the scope of the research, it was stated that tourist guide academicians produced 1415 publications in total; It was determined that among these publications, the most publications were made in 626 papers (communiqués) and 488 articles, followed by 279 book chapters and 22 books. In terms of the language of publication, Turkish publications came to the fore.
\end{abstract}

Keywords: Tourism Researches, Tourist Guiding, Guide Academician, Bibliometric Analysis, Tableau. 


\section{GİRIŞ}

Turist rehberliği, 12.06.2012 tarihinde çıkarılan 6326 sayılı "Turist Rehberliği Meslek Kanunu" ile meslek olarak kabul edilmiştir. Çıkarılan bu kanun turist rehberliği mesleği ve turist rehberleri için önemli bir dönüm noktası olmuştur. 6326 sayılı kanun ile birlikte yasal zeminde karşılık bulunması ve mesleğin daha iyi noktalara taşınması için Turist Rehberleri Birliği (TUREB) tarafindan girişimlere başlanmıştır. Bu vesileyle Türkiye'deki tüm bölgelere rehber odaları açılmış, bu odalara üye olma zorunluluğu getirilmiş; kaçak rehberlik ile mücadele, tüm mecralarda rehberleri temsil etme, meslektaşlar arası ilişkileri düzenleme, ruhsatname ve çalışma kartı alma şartlarını belirleme, bununla birlikte turist rehberliği eğitiminin nasıl olması gerektiği ve hangi derslerin verileceği (TUREB, 2020) gibi konulara kadar birçok alanda çalışmalar yapılmıştır. Bu konular arasında yer alan eğitim ve müfredatın turist rehberi adaylarına okutulması konusu oldukça önem kazanmıştır.

Türkiye' de turist rehberliği eğitimi örgün ve yaygın eğitim şeklinde verilmektedir. Örgün eğitim, önlisans düzeyinde üniversitelerin meslek yüksekokullarında iki yıllık programlarda, lisans düzeyinde fakülte veya yüksekokulların bünyesinde ve yüksek lisans düzeyinde sosyal bilimler enstitüleri bünyesinde yürütülmektedir. Yaygın eğitim ise 2012 yılına kadar Kültür ve Turizm Bakanlığı tarafından açılan kurslar kapsamında verilmiştir. 2012 yılında meslek yasasının çıkmasıyla beraber ihtiyaç duyulan bölge ve diller birlikler tarafindan düzenlenen sertifika programları ile verilmeye başlanmıştır (Resmi Gazete, 2012). Bu durum eğitimde ikiliğe neden olmakta ve turizm/turist rehberliği eğitimini olumsuz etkilemektedir. Eğitimde birliğin olmamas1 eğitim kalitesini düşürmekte, firsat eşitsizliği yaratmaktadır (IRO, 2020). Diğer taraftan rehberlik bölümlerinin isimlendirilmesinde önlisans eğitimi verilen programlar için turist rehberliği kullanılırken lisans eğitimi verilen programlar için turizm rehberliği adının tercih edilmesi örgün turist rehberliği eğitiminde de yaygın eğitimdeki ikircikliğe benzer bir durumun söz konusu olduğunu göstermektedir (Pelit ve Katırcıŏlu, 2018: 78).

Türkiye' de yükseköğretim okullaşma oranının 2006 yılı sonrasında hızla artmaya başlaması ile 2006 yılına kadar 77 olan üniversite sayısı 2020 yılı itibariyle 207’ye (YÖK, 2020) ulaşmış ve tüm illere yaygınlaştırılmıştır. Üniversite sayılarının artışı ile eğitim verilen program türlerinde de çeşitlilik artarak yüz yüze eğitim yükseköğretim kontenjanları da artmıştır (Günay ve Günay, 2011). Yükseköğretimdeki bu ivmelenme içerisinde turizm eğitimine yönelik eğitim veren birimler de yer almaya başlamış ve Turizm İşletmeciliği ve Otelcilik Yüksekokulları Turizm Fakültelerine dönüştürülme sürecine girmiştir. Bu kapsamda 2009 yılında Türkiye'de Turizm Fakültelerinin kurulmaya başlaması ile Yüksek Öğretim Kurumu'nun (YÖK) fakülte tanımına uygun biçimde, turizm alanında akademik bilgi üretimine daha fazla odaklanan ve alanda uzun yıllardır var olan doktora programına uygun olarak turizm konusunda uzmanlaşacak akademisyen yetiştirmeyi hedefleyen bir politika değişikliği gerçekleşmiştir (Gülcan, 2011: 4). Bu durum turizm alanında çalışmak isteyen ve istihdam edilen akademisyen sayısını artırmaya başlamış ve Turizm Fakülteleri ve Turizm/Turist Rehberliği Bölümleri özelinde akademik kadrolaşmanın da artmasının önünü açmıştır. Nitekim Turizm/Turist Rehberliği Bölümlerinde görev yapan akademisyenler üzerine yapılmış çalışmalarda bu ivmelenme daha net görülmektedir. Arslantürk, Küçükergin ve Apalı (2016: 918) çalışmalarında üniversitelerin turizm rehberliği; seyahat işletmeciliği ve turizm rehberliği bölümlerinin akademik personel sayısının 112 olduğunu vurgularken bu sayıların turizm rehberliği bölümlerinde Ocak 2018 itibariyle 118 (Doğancılı ve Karaçar, 2018); Mart 2018 itibariyle 201 (Aylan ve Başoda, 2018) Ocak 2019 itibariyle 32 fakülte ve 27 meslek yüksekokulda toplam 271 (Baytok, Boyraz ve Kabakulak, 2019) ve Kasım 2019 itibariyle 38 fakülte ve 26 meslek yüksekokulda toplam 290 (Boyraz ve Kabakulak, 2020) düzeyine ulaştığ 1 görülmektedir.

Turizm rehberliği bölümlerinde artan akademisyen sayısı beraberinde gerek turizm alanında gerek turizm rehberliği alanında yapılan akademik çalışmaların ve bilimsel yayınların nicelik bakımından çoğalmasına ve yayın türü bakımından çeşitlenmesine katkı sağlamıştır. Bu 
doğrultuda ilgili alana yönelik makale, lisansüstü tez, kitap, kitap bölümü, proje ve bildiri türlerinde bilimsel yayınlar ve çalışmalar gerçekleștirilmiştir. 2006-2017 yılları arasında turizm rehberliği alanında 32 ulusal makalenin yazıldığı (Çapar, Toksöz ve Dönmez, 2018); 2017 yılı itibariyle ise etki faktörü en yüksek beş yabancı dergide 1980-2019 yılları arasında yine aynı alanda 75 makalenin yayımlandığı belirlenmiştir (Kaygalak Çelebi ve Kırlar Can, 2019). Bununla birlikte 1989-2011 yılları arasında turist rehberleri ve turist rehberliği üzerine 30; 2012-2018 yılları arasında ise 47 tez yazıldığı görülmüştür. Özellikle 2015-2016 yılları arasında yazılan tezlerin 26'sı iki yıllık bir süreç içinde yazılmıştır (Özsoy ve Çokal, 2018). Diğer taraftan Boyraz ve Kabakulak (2020) ise, turizm/turist rehberliği bölümlerinde görev yapan akademisyenlerin 6601 yayın (makale, bildiri, kitap, kitap bölümü, proje) yaptıklarını tespit etmiş; bu yayınlar arasında çalışma kartına sahip rehber akademisyenler tarafından yapılan 272 çalışmanın da yer aldığı vurgulanırken 57 rehber akademisyenin turizm rehberliği eğitiminde önemli bir yere $(\% 19,7)$ sahip olduğuna dikkat çekmişlerdir. İlgili araştırmada, rehber akademisyenlerin yapmış oldukları bilimsel yayınlar da sayılarına göre yayın dili, yayın alanı ve yayın türü değişkenlerine göre ele alınarak değerlendirilmiş ve bu şekilde rehber akademisyenler ile ilgili konular da bibliyometrik çalışmaların bir parçası haline gelmeye başlamıştır. Dolayısıyla, turist rehberi akademisyenlerin sektör tecrübelerine bağlı olarak araştırmalarında çalıştıkları bölgeler, destinasyonlar, turist gruplar1, rehberlik yapılan dil vb. gibi durumları rehber akademisyenlerin akademik çalışmalarına ne kadar yansıttıkları ortaya konmak istenmiştir.

Toplumun nitelikli insan gücü gereksinimlerinin karşılanması için üniversitelerde nitelikli akademisyenlerin varlığı (Karataş, Özen ve Gülnar, 2017) kadar bir alanın/bilim dalının kendi temellerinin oluşturulması, sınırlarının belirlenmesi ve gelişiminin devam ettirilmesinde o alanda eğitim almış araştırmacıların istihdam edilmesi de önemlidir. Nitekim uygulamalı bir alan olan turizmde ise "Turizm alanında akademik unvana sahip olan ve/veya bu alanda alanyazına önemli katkılar sağlayan bilimsel çalışmaları bulunan kişiler"in (TUADER, 2020) istihdamı kadar alan deneyimi yüksek sektör tecrübesine sahip bireylerin belirli düzeyde akademik personel olarak istihdam edilmesi de önem arz etmektedir. Bu doğrultuda Turizm Rehberliği Bölümlerinde profesyonel turist rehberlerinin akademisyen olarak yer alması ilgili alandaki eğitim kalitesini olumlu düzeyde etkilemesi kaçınılmaz olacaktır. Çünkü sektör-üniversite işbirliği çerçevesinde turist rehberi akademisyenler, her iki alanda da taraf olarak yer alarak hem sektör hem de üniversite açısından olumlu ve olumsuz değerleri bir arada görerek iki yönlü gelişimin önünü açabilmektedir. Bununla birlikte sektör-üniversite işbirliği üzerinde düzenleyici rolü olan kamu açısından da katkılar sağlayabilmektedir. Tüm paydaşlar açısından ortaya çıkarılacak katkılar ise rehber akademisyenlerin yaptıkları/yapacakları bilimsel yayınlar aracılığ 1 ile gerçekleşmektedir. Dolayısıyla bu noktada rehber akademisyenlerin yayınlarının belirli dönem aralıklarında incelenerek görev yaptıkları alana (turizm rehberliği) katkı düzeyleri belirlenmeli, çalışma/yayın alanlarının görev yaptıkları alan ile ne kadar ilişkili/uyumlu ve paralel olduğu ortaya koyulmalıdır. Yapılan araştırma da bu gerekçe ile turist rehberi akademisyenlerin yayınlarının veri görselleştirme tekniği ile bibliyometrik açıdan değerlendirilmesini hedeflemektedir.

\section{LITTERATÜR TARAMASI}

Zaman içinde akademik hayatın tüm alanlarında yapılan çalışmaların artması, araştırmacıların yapılan çalışmalara kolayca ulaşabilmesi, merak ettikleri konularda meydana gelen değişimlerin takibini kolayca yapmaları, çalışma alanlarının geçirdiği evreleri, akademisyen sayılarının değişimi ve unvanlara göre akademisyenlerin dağılımlarını bir arada sunabilecek başucu rehberi niteliğinde sayılabilecek bibliyometrik çalışmalar son y1llarda ciddi bir biçimde artmaya başlamıştır. Farklı alanlarda yapılan ulusal ve uluslararası bibliyometrik çalışmalara ek olarak turizm alanında yapılan çalışmaların derlenmesi ve turizm disiplininin gelişimine ve alan yazınının büyümesine paralel olarak bu alanda üretilen yayınlara yönelik bibliyometri verilerini ihtiyaç haline getirmiştir (Hall, 2011). Turizm alanında yer alan yerli ve yabancı dergilerdeki makaleler; Ulusal Tez Merkezi'nde yer alan tezler, ulusal ve uluslararası kongrelerde sunulmuş bildiriler; kitaplar ve kitap bölümlerinin birçok parametre 
açısından bibliyometrik analizi yapılmıș ve turizm alanında farklı yerlerde dağınık duran veriler bir araya getirilerek hem turizm disiplinin geldiği nokta hem de tez (Özsoy ve Çokal, 2018), makale (Kaygalak Çelebi ve Kırlar Can, 2019; Baytok, vd., 2019; Boyraz ve Kabakulak, 2020), bildiri (Şahin ve Acun, 2015; Aylan ve Başoda, 2018; Çapar, Toksöz ve Dönmez, 2018) ve diğer yayın türlerindeki çalışmalar bir bütün halinde sistemli bir şekilde bir araya getirilmiştir.

Turizm disiplini çok geniş bir alana yayıldığı için ve birçok faklı disiplinle (multidisipliner) bir arada çalışma alanı ortaklığı bulunduğundan araştırmalar genel olarak birkaç değişkenin incelenmesiyle sınırlı kalmıştır. Daha önce yapılmış olan bibliyometrik çalışmalar incelendiğinde araştırmacıların çizmiş oldukları çerçeve doğrultusunda belirlemiş oldukları araştırma sinırlılıklarından dolayı daha genelden daha özele (örn: turizmde yapılan tezler yerine sürdürülebilirlik alanında yapılan tezler şeklinde) çalışmalar gerçekleştirilmiştir. Bu kapsamda turizmin bir parçası olan turizm rehberliği ile ilgili çalışmalarda da kendini göstermiştir (Şahin ve Acun, 2015; Aylan ve Başoda, 2018; Çapar vd., 2018; Kaygalak Çelebi ve Kırlar Can 2019; Baytok, vd. 2019; Boyraz ve Kabakulak, 2020).

Literatürde Turizm Rehberliği ile ilgili araştırmalara yönelik yapılan bibliyometrik çalışmalarda; Şahin ve Acun (2015) 1990-2015 yılları arasındaki Ulusal Turizm Kongrelerinin bildirilerini ve 1989-2015 yılları arasında 26 yıllık bir dönemde turist rehberliği alanında yazılan yüksek lisans ve doktora tezlerini; Çapar vd. (2018) 2005-2017 yılları arasındaki tez, makale ve bildirileri; Özsoy ve Çokal (2018) 1989-2018 yılları arasındaki lisansüstü tezleri; Black vd. (2018) uluslararası literatürde yer alan 1980-2016 yılları arasındaki makaleleri; Kaygalak vd. (2019) Scimago dergi sıralamasında (2017) etki faktörü en yüksek beş derginin 1980-2019 yılları arasındaki makalelerini incelemişlerdir. Bu çalışmalar incelendiğinde genel olarak tez, makale, bildiri alanlarında genel çalışmalar yapılmış ve daha önce araştırma sınırlılıkları çerçevesinde eksik bırakılan yönler farklı araştırmacılar tarafindan genelden özele (turizm/turist rehberliği bölümündeki akademisyenlerin profili, daha sonra akademik yayınların sayısı) olacak şekilde araştırmacılar tarafından ortaya konmuştur. Bu kapsamda Baytok vd. (2019); Boyraz ve Kabakulak (2020) çalışmalar gerçekleştirmiş̧lerdir.

Baytok ve arkadaşlarının (2019) turizm/turist rehberliği bölümlerinde görev yapan akademisyenlerin profillerini inceledikleri çalışmada Türkiye'de 32 fakülte ve yüksekokul ile 28 meslek yüksekokulda turizm rehberliği eğitimlerinin sürdürüldüğ̈̈; fakülte ve yüksekokullarda 196 ve meslek yüksekokullarında ise 75 öğretim elemanının görev yaptığı belirlenmiştir. Bu akademisyenlerin çoğunluğunun erkek ve en fazla doktor öğretim üyesi unvanına sahip olduğu; akademisyenlerin 58'inin rehberlik çalışma kartına sahip iken eylem durumu bakımından sadece 36'sının çalışma kartının aktif olduğu vurgulanmıştır. Çalışma kartı sahibi rehber akademisyenlerin bağlı bulundukları odalar açısından ise en fazla ÇARO, İRO ve İZRO'ya (her bir oda 9 akademisyen) bağlı oldukları ortaya çıkmıştır.

Boyraz ve Kabakulak'1n (2020) Türkiye'de turizm/turist rehberliği bölümlerinde görev yapan tüm akademisyenlerin bilimsel yayınlarını inceldikleri çalışmada, akademisyenlerin unvanlarına göre sırasıyla; \%44,4'ü doktor öğretim üyesi, \%18,0'i araştırma görevlisi, \%16,7'si öğretim görevlisi, \%15,1'i doçent doktor ve \%5,9'u profesör unvanına sahip oldukları; akademisyenlerin toplamda 6601 yayın ürettikleri, en fazla yayının 2817 ile bildiri (tebliği) ve 2334 ile makale türünde yapıldığı, bunu 928 kitap bölümünün ve 141 kitabın takip ettiği belirlenmiştir. Akademisyenlerin en fazla Türkçe dilinde yayın yaptıkları; rehberlik çalışma kartı sahiplik durumu bakımından yayınların \%78,1'inin çalışma kartına sahip olmayan akademisyenler tarafindan gerçekleştirildiği vurgulanmıştır. Araştırmada ayrıca \%6,5'i doğrudan turizm rehberliği alanında olmak üzere, akademisyenlerin yaptıkları yayınların toplamda \%76,5'inin turizm alanında, geri kalan \%23,5'inin ise turizm dışındaki diğer bilim alanlarında (coğrafya, finans, halkla ilişkiler, işletme, iktisat, organizasyon, pazarlama, psikoloji, sosyoloji, tarih vb.) gerçekleştirildiği tespit edilmiştir. 
Turizm Rehberliği alanında tez, makale, bildiri türünde bibliyometrik araştırmalar olmasına rağmen daha önce yapılan bibliyometrik çalışmalarda veri görselleştirme tekniğinin kullanılmadığı tespit edilmiştir. Boyraz, Kabakulak ve Mutlu (2020) tarafından turizm alanında hazırlanmakta olan tezlerin değerlendirilmesinde veri görselleştirme analizi kullanılmış, lisansüstü tezler belirlenen parametreler açısından çapraz tablolar eşliğinde ele alınarak araştırmacıların en çok hangi konulara önem verdiği grafiklerle daha anlaşılır hale getirilmiştir. Bu kapsamda 538 adet tez değerlendirilmiştir. Bu kapsamda tezlerde en çok otel, turist, destinasyon, gastronomi, kültür, konaklama, rehber, seyahat, deneyim ve yiyecek kavramlarının öne çıktığı; en çok vurgu yapılan destinasyonların Türkiye, Antalya ve Kapadokya; yöntem bakımından en sık kullanılan sözcüğünün "etkisi”; örneklem açısından turizm işletmeleri çalışanları olduğu; çalışma yapılan konu ve alanları bakımından ise "yönetim ve organizasyon, pazarlama ve sürdürülebilirlik" başlıklarının ön plana çıktığı vurgulanmıştır.

Yukarıda yer alan çalışmalar incelendiğinde literatürde turizm/turist rehberliği alanında 2015 yılından günümüze kadar birçok bibliyometrik çalışmanın (tez, makale, bildiri vd.) yapıldığı görülmüştür. Yapılan bu çalışmalar turizm/turist rehberliği alanının gelişmesine, halkaların birbirine bağlanmasına ve bir yol haritasının çıkarılmasına vesile olmuştur. Önceki yıllarda genel olarak çalış1lan bibliyometrik analizler artan çalışmalar sayesinde turizm/turist rehberliği gibi daha spesifik alanlarda araştırmacılara çalışma imkanı sağlamış ve bu çalışmalara bir dayanak oluşturmuştur. Daha önce ifade edildiği gibi turizm rehberliği bölümleri bir bütün olarak ele alınmış ve araştırmaya rehberlik bölümlerinde görev yapan tüm akademisyenler dâhil edilmiş; ardından aynı şekilde rehberlik bölümlerinde çalışan tüm akademisyenlerin yayınları incelenmiştir. Yapılan çalışmalar her ne kadar turizm/turist rehberliği bölümlerine önemli kazanımlar ve bazı yol haritaları sunsa da alan deneyimi yüksek, sektör tecrübesine sahip rehber akademisyenlerin turizm/turist rehberliği bölümlerinde eğitim kalitesi süreçlerinin gelişmesi ile birlikte farkındalığın yanı sıra turizm/turist rehberliği mesleğinin bilinirliliğinin artırılmasına ve saygın bir meslek haline gelmesine katkı sunacak olması; yasa, yönetmelik ve uygulamalardaki eksikliklerin tespit edilip turist rehberlerinin çalışma ve yaşam koşullarına etkilerini ve rehber adaylarının rehberlik mesleğinde kariyer yapmalarına karar vermede önemli etkileri olacağının düşünülmesi, turizm/turist rehberliği bölümlerinde görev yapan rehber akademisyenlerin çalışmalarına 1şık tutması bu araştırmayı önemli kılmaktadır. Yöntem açısından ise, daha önce turizm rehberliği ile ilgili bibliyometrik analizin veri görselleştirme tekniğiyle bir arada sunulduğu ve çalışma kartına sahip akademisyen rehberler özelinde bilimsel yayınların değerlendirildiği bir araştırmaya rastlanmamış olması çalışmanın özgünlük değerini artırmaktadır. $\mathrm{Bu}$ nedenle turist rehberi akademisyenlerin yayınlarının veri görselleştirme tekniğiyle bibliyometrik analizinin yapılması araştırmanın temel amacı olarak belirlenmiştir.

\section{YÖNTEM}

$\mathrm{Bu}$ araştırmanın amac1, yükseköğretim düzeyinde eğitim veren kurumlarda çalışan turizm rehberliği bölümlerindeki çalışma kartına sahip olan turist rehberi akademisyenlerin bilimsel yayınlarının çeşitli değişkenler açısından incelenmesidir. Araştırma kapsamında turist rehberi akademisyenlerin demografik özellikleri (cinsiyet, lisans eğitim alanı, çalışılan kurum türü, unvan, idari görev durumu), sahip oldukları çalışma kartının nitelikleri (eylem durumu, dil sayısı, dil türü, bağlı bulunan oda), yapmış oldukları bilimsel yayınların; türü (makale, kitap, kitap bölümü, bildiri), yayın dili (Türkçe, Yabancı), yayın niteliği (ulusal, uluslararası) ve kurumlar arası işbirliği durumu açısından belirtilen değişkenlere göre değerlendirilmesi amaçlanmıştır.

Araştırmanın evrenini, Türkiye'deki üniversitelerin turizm rehberliği eğitimi veren önlisans düzeyinde meslek yüksekokulları ile lisans düzeyinde fakülte ve yüksekokullarda aktif olarak çalışan ve T.C. Kültür ve Turizm Bakanlığı'ndan ruhsatname sahibi ve Turist Rehberleri Birliği tarafından verilen rehberlik çalışma kartına sahip olan akademisyenlerin yayınları oluşturmaktadır. Araştırmada ilk olarak, üniversitelerin web siteleri ve YÖK Akademik Veri Tabanı aracılığıyla 30 Aralık 2019 tarihi itibariyle Turizm Rehberliği bölümlerinde görev yapan 
akademisyenler listelenmiş ve Türkiye Turist Rehberleri Birliği Rehber Veri Tabanı üzerinden hangi akademisyenlerin çalışma kartına sahip olduğu tespit edilmiştir. İkinci aşamada ise turist rehberi akademisyenlerin yayınlarına ilişkin verilerin toplanması için nitel araştırma yöntemlerinden doküman-arşiv tarama ile YÖK Akademik Veri Tabanı tekrar taranmıştır. 01-29 Şubat 2020 tarihleri arasında gerçekleştirilen veri toplama sürecinde turizm rehberliği bölümlerindeki rehber akademisyenlerin yayınları belirtilen değişkenlere göre tek tek kayıt altına alınmıştır.

Türkiye' deki üniversitelerde turizm rehberliği eğitimi veren bölümlerde 65 turist rehberi akademisyenin görev yaptı̆̆ 1 tespit edilmiş olup 6'sına ilişkin herhangi bir yayın bilgisine erişilemediği için (yeni atanmış olması, YÖK Akademik Veri Tabanında veri girişinin bulunmaması vb.) araştırmaya dâhil edilmemiştir. Böylece araştırmanın örneklemini 30'u devlet ve 2'si vakıf olmak üzere 32 ayrı üniversitede görev yapan rehberlik çalışma kartına sahip 59 akademisyen oluşturmaktadır. Bilimsel araştırma projelerinin tamamlanmasında proje konusu ile ilgili bir çıktının (makale, kitap, bildiri, tez vb.) sunulması şartı arandığı için projeler araştırma kapsamında çıktı türüne bakılmaksızın bağımsız bir yayın türü olarak kabul edilmesine rağmen proje çıktılarının gerçekleştirilen proje ile aynı/benzer adı taşıması nedeniyle ikili çakışmalardan dolayı projeler (76) araştırmaya dahil edilmemiştir. Bununla birlikte ansiklopedi maddeleri (61) de yayın kapsamında değerlendirmelere dahil edilmemiştir.

Erişim sağlanan yayınların değerlendirilmesinde iki ayrı yöntem bir arada kullanılmıştır. Rehber akademisyenlerin demografik bilgileri ve çalışma kartlarının nitelikleri ile yayınların niteliklerine ilişkin tanımlayıcı veriler betimsel analiz (yüzde ve sıklık analizi, aritmetik ortalama) ile çapraz tablolar halinde incelenmiştir. Yayınların içeriklerine ve kapsamlarına ilişkin değerlendirmeler ise çalışma başlıkları üzerinde gerçekleştirilen veri görselleştirme analizi ile yapılmıştır. Verilerin görselleştirilmesinde interaktif bir yazılım olan Tableau kullanılmış ve araştırma verilerinin görselleştirilmesinde graph (area, bar, density, line, pie, text), packed bubbles, treemaps teknikleri tercih edilmiştir. Böylelikle yapılan çalışmalarda en çok hangi konulara önem verildiği grafik ve şekillerle daha anlaşılır hale getirilmiştir.

\section{BULGULAR}

Araştırmaya dâhil edilen üniversitelerin turizm rehberliği bölümlerinde kadrolu rehberlik çalışma kartına sahip 59 akademisyenin yaklaşık \%95'i fakültelerde, \%5'i yüksekokullarda olmak üzere 32 ayrı kurumda görev yapmaktadır. 17 üniversitede yalnızca bir turist rehberi akademisyen görev yaparken 10 üniversite ikişer, üç üniversitede üçer, iki üniversitede dörder ve bir üniversitede ise beș turist rehberi akademisyen çalışmaktadır (Grafik 1). Bunların \%55.9'u kadın iken \%44.1'i erkektir. Akademisyenlerin unvanlarına göre sırasıyla; \%5.1'i profesör, \%13.6'sı doçent doktor, \%39.0'u doktor öğretim üyesi, \%35.6'sı araştırma görevlisi ve \%6,8'i öğretim görevlisi unvanına sahiptir. Bununla birlikte idari görev bakımından turist rehberi akademisyenlerin \%22.0'sinin turizm rehberliği bölümlerinde bölüm başkanlığı görevi yürütmektedir. Eğitim aldıkları alanlar bakımından akademisyenler incelendiğinde, akademisyenlerin \%88,1'inin turizmle ilgili (turizm işletmeciliği, konaklama işletmeciliği, seyahat işletmeciliği, yiyecek-içecek işletmeciliği, turizm rehberliği vb.) bir bölümden/programdan, \%11.9'unun ise turizm dışındaki diğer alanlardan (arkeoloji, işletme, yabancı dil(ler) eğitimi vb.) lisans eğitim derecesine sahip olduğu tespit edilmiştir. 
Grafik 1. Üniversitelere Göre Kadrolu Turist Rehberi Akademisyen Sayısı

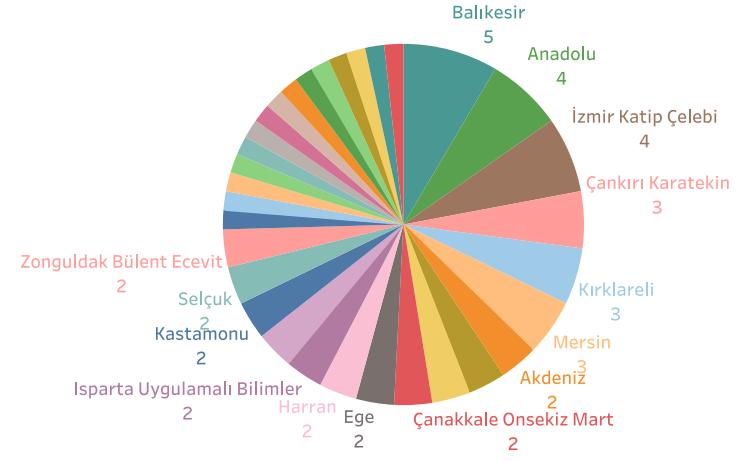

Turist rehberi akademisyenlerin çalışma kartlarında yer alan niteliklerine ilişkin bulgulara Tablo 1 'de yer verilmiştir. Bu doğrultuda akademisyenlerin eylem durumu bakımından rehberlik çalışma kartlarının \%62.7'si aktif ve \%37.3'ü pasif iken her iki durumda da kadınların oranı erkeklerden fazladır. Çalışma kartına ekli olan dil sayıları bakımından \%93.2 ile rehber akademisyenlerin büyük çoğunluğunun tek bir yabancı dil bildikleri; dil türü bakımından ise başta \%88.1 ile İngilizce olmak üzere yedi farklı yabanc1 dile (Almanca, Bulgarca, Fransizca, İspanyolca, İtalyanca, İngilizce ve Japonca) ilişkin yetkinliklerinin olduğu belirlenmiştir. Rehber akademisyenler Türkiye Turist Rehberleri Birliği'ne (TUREB) bağlı olarak faaliyet gösteren 13 üye oda arasından 12'sine çeşitli sayılarla üye durumunda iken Bursa Turist Rehberleri Odası'na (BURO) bağlı olan herhangi bir turist rehber akademisyenin olmadığı görülmektedir.

Tablo 1. Turist Rehberi Akademisyenlerin Çalışma Kartlarında Yer Alan Özellikleri

\begin{tabular}{|c|c|c|c|c|c|c|c|c|c|c|c|}
\hline \multirow{2}{*}{ Nitelik } & \multirow{2}{*}{ Türü } & \multicolumn{2}{|c|}{ Kadın } & \multicolumn{2}{|c|}{ Erkek } & \multicolumn{2}{|c|}{ TOPLAM } & \multirow{2}{*}{ Nitelik } & \multirow{2}{*}{ Türü } & \multicolumn{2}{|c|}{ TOPLAM } \\
\hline & & $\mathbf{f}$ & $\%$ & f & $\%$ & f & $\%$ & & & $\mathbf{f}$ & $\%$ \\
\hline \multirow{2}{*}{$\begin{array}{l}\text { Eylem } \\
\text { Durumu }\end{array}$} & Aktif & 20 & 33.9 & 17 & 28.8 & 37 & 62.7 & \multirow{13}{*}{$\begin{array}{l}\text { Bağlı } \\
\text { Olunan } \\
\text { Rehberler } \\
\text { Odası }\end{array}$} & ÇARO & 9 & 15.3 \\
\hline & Pasif & 13 & 22.0 & 9 & 15.3 & 22 & 37.3 & & İंRO & 8 & 13.6 \\
\hline \multirow{2}{*}{ Dil Sayısı } & Tek & 31 & 52.5 & 24 & 40.7 & 55 & 93.2 & & İZRO & 8 & 13.6 \\
\hline & $\dot{I} k i$ & 2 & 3.4 & 2 & 3.4 & 4 & $\begin{array}{l}6.8 \\
\end{array}$ & & ANRO & 7 & 11.9 \\
\hline \multirow{7}{*}{ Dil Türü } & Ingilizce & 30 & 50.8 & 22 & 37.3 & 52 & 88.1 & & ARO & 7 & 11.9 \\
\hline & $\begin{array}{l}\text { Ingilizce / } \\
\text { Ispanyolca }\end{array}$ & 2 & 3.4 & - & - & 2 & 3.4 & & TRO & 4 & 6.8 \\
\hline & $\begin{array}{l}\text { Ingilizce / } \\
\text { Fransizca }\end{array}$ & - & - & 1 & 1.7 & 1 & 1.7 & & NERO & 3 & 5.1 \\
\hline & $\begin{array}{l}\text { Ingilizce/ } \\
\text { Japonca }\end{array}$ & - & - & 1 & 1.7 & 1 & 1.7 & & ŞURO & 3 & 5.1 \\
\hline & Almanca & - & - & 1 & 1.7 & 1 & 1.7 & & ATRO & 3 & 5.1 \\
\hline & Bulgarca & 1 & 1.7 & - & - & 1 & 1.7 & & ADRO & 2 & 3.4 \\
\hline & Italyanca & - & - & 1 & 1.7 & 1 & 1.7 & & GARO & 1 & 1.7 \\
\hline \multirow{2}{*}{\multicolumn{2}{|c|}{ TOPLAM }} & \multirow{2}{*}{33} & \multirow{2}{*}{55,9} & \multirow{2}{*}{26} & \multirow{2}{*}{44,1} & \multirow{2}{*}{59} & \multirow{2}{*}{100.0} & & MURO & 1 & 1.7 \\
\hline & & & & & & & & & BURO & - & - \\
\hline
\end{tabular}

f: Frekans, \%: Oran

Turist rehberi akademisyenlerin toplamda 1415 yayın ürettikleri tespit edilmiştir. Bunlar arasında en fazla yayının 626 ile bildiri (tebliğ) ve 488 ile makale türünde yapıldığı, bunu 279 kitap

December-2020 Vol:5 No:2 International Journal of Turkic World Tourism Studies 
bölümünün ve 22 kitabın takip ettiği belirlenmiştir. Tablo 1'de akademisyenlerin yayınlarının çeşitli niteliklerine göre dağılımlarına ilişkin bulgulara yer verilmiştir. Buna göre yayın dili açısından Türkçe'nin ağırlıklı olarak öne çıktığı ve ortalama her dört yayından üçünün Türkçe dilinde olduğu, yabancı dildeki yayınların \%99 ile neredeyse tamamının İngilizce dilinde yapıldığı tespit edilmiştir.

Yayınların nitelik olarak yarısından fazlasının uluslararası nitelikli dergi, yayınevi ve bilimsel etkinlik çıktılarında yer aldığı görülmektedir. Yapılan çalışmalarda tek yazarlılık oranı $\% 26.2$ iken yayın başına ortalama 2.2 akademisyen yazar olarak yer almıştır. Diğer taraftan yayınlarda ortak yazarlı çalışma oranı \%73.8 iken farklı üniversitelerde görev yapan akademisyenler arasında işbirliği yapılarak gerçekleştirilen yayınların oranı \%37.5 ile önemli bir düzeydedir. Ortaya çıkan bu durum ortalama olarak her üç yayından; birinin tek bir yazar tarafindan, diğerinin aynı kurum bünyesinde görev yapan öğretim elemanların ortaklığı ile, ötekisinin ise farklı kurumlarda görev yapan öğretim elemanlarının işbirliği ile hazırlandığını göstermektedir.

Tablo 2. Turist Rehberi Akademisyenlerin Yayınlarının Niteliklerine Göre Dağılımları

\begin{tabular}{|c|c|c|c|c|c|c|c|}
\hline Nitelik & Türü & f & $\%$ & Nitelik & Türü & f & $\%$ \\
\hline \multirow{4}{*}{ Yayın Türü } & Bildiri & 626 & 44.2 & \multirow{10}{*}{$\begin{array}{l}\text { Yayın } \\
\text { Başı } \\
\text { Yazar } \\
\text { Sayısı }\end{array}$} & Bir & 371 & 26.2 \\
\hline & Kitap & 22 & 1.6 & & İki & 540 & 38.2 \\
\hline & Kitap Bölümӥ & 279 & 19.7 & & Üç & 385 & 27.2 \\
\hline & Makale & 488 & 34.5 & & Dört & 94 & 6.6 \\
\hline \multirow{2}{*}{ Yayın Dili } & Türkçe & 1050 & 74.2 & & Beș & 7 & 0.5 \\
\hline & Yabancl & 365 & 25.8 & & Alt1 & 10 & 0.7 \\
\hline \multirow{2}{*}{ Yayın Niteliği } & Ulusal & 677 & 47.8 & & Yedi & 5 & 0.3 \\
\hline & Uluslararast & 738 & 52.2 & & Sekiz & 1 & 0.1 \\
\hline \multirow{3}{*}{$\begin{array}{l}\text { Kurumlar Arası } \\
\text { İşbirliği }\end{array}$} & Yok - Tek Yazarlı & 371 & 26.2 & & Dokuz & 1 & 0.1 \\
\hline & Yok - Kurum $\dot{I}_{c ̧ i}$ & 513 & 36.3 & & On & 1 & 0.1 \\
\hline & Var - Farklı Kurumlar & 531 & 37.5 & \multicolumn{2}{|c|}{ TOPLAM } & 1415 & $\% 100.0$ \\
\hline
\end{tabular}

f: Frekans, \%: Oran

Turist rehberi akademisyenlerin yayınlarının yıllara göre dağılımı, yıl bazında yayınlara katkı sağlayan toplam yazar sayısı ile yıllık düzeyde yazar başı üretilen ortalama yayın sayısı karşılaştırmalı olarak Grafik 2'de ele alınmıştır. Bu kapsamda turist rehberi akademisyenlerin yapmış olduğu ilk yayın 1984 yılında iken takip eden 20 yıllık dönemde bilimsel yayın üretkenliklerinin çok düşük düzeyde kaldığı ve yok denecek kadar az olduğu görülmektedir. 2005 yılı itibariyle turist rehberlerinin üniversitelerde istihdam edilme oranının artışına paralel olarak yayın sayıları da artışa geçmiş ve aynı zamanda yazar başına düşen ortalama yayın sayısı da yükselmiştir. Bu eğilim 18 Aralık 2015 tarihinde “Akademik Teşvik Ödeneği Yönetmeliği”nin yürürlüğe girmesi ile en yüksek ivmeye ulaşmış ve 2016 yılında tüm zamanların en fazla yayın sayısına ulaşılmıştır. Takip eden yıllarda üniversitelerde istihdam edilen turist rehberi akademisyen sayısı artmış ve belirtilen yönetmelik çeşitli güncellemelerle yürürlükte olmasına rağmen üretilen yayınların niceliği düşüş eğilimine girmiştir. 
Grafik 2. Yıllara Göre Yayın ve Yazar Sayısı ile Ortalama Yazar Başı Yayın Sayısı

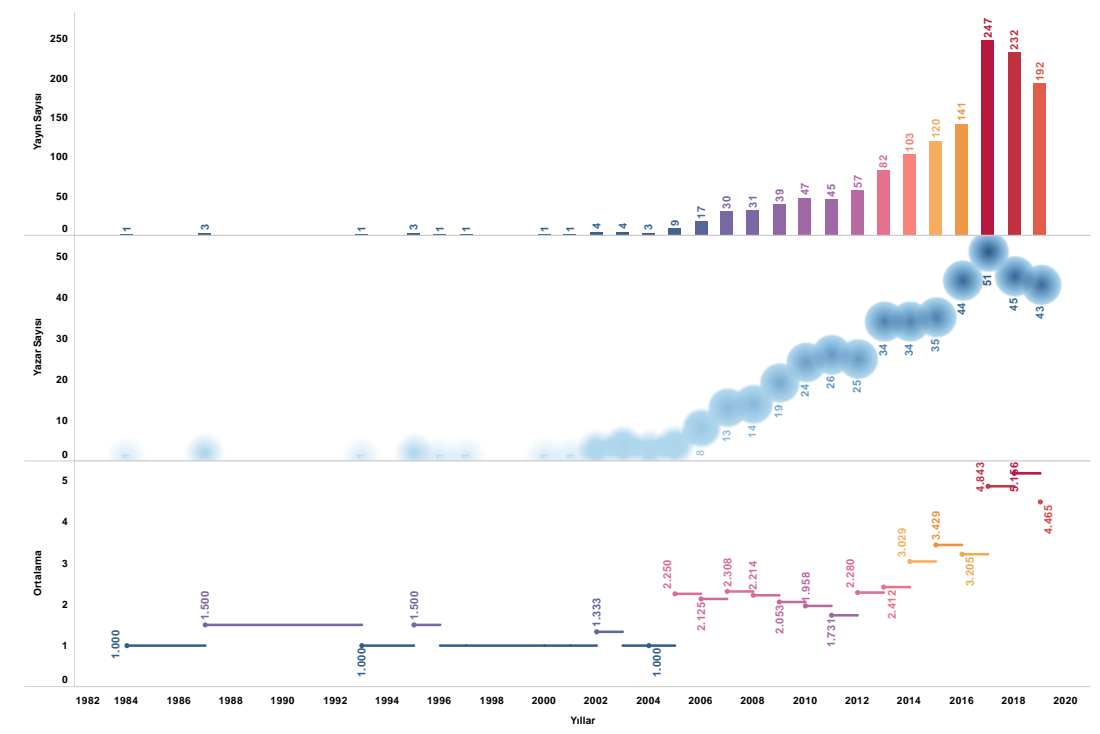

Araştırmanın takip eden aşamasında, turist rehberi akademisyenlerin yayınlarının başlıkları incelenmiş ve kullanılan sözcükler genelden özele çeşitli gruplandırmalarla görselleştirilmiştir. Bu kapsamda ilk olarak çalışma başlıklarında herhangi bir gruplandırma/sınıflandırma veya eleme yapılmadan Türkçe en fazla tekrar eden sözcükler analiz edilmiştir. Veri analizinde rakamlar, edat, bağlaç ve sözcük ekleri dikkate alınmamış olup toplamda 941 sözcük tespit edilmiştir. Sözcükler toplamda 8633 defa vurgulanmıştır. Tekrar eden, benzer sözcüklerin birleştirilmesi ile sözcük sayısı 570'e düşürülmüş ve en fazla kullanılan ilk 100 sözcük text graph tekniği ile görsel hale getirilmiştir (Şekil 1).

Çalışma başlıklarındaki sözcükleri görsel analiz için bir diğer grup değişkeni olarak çalışma alanı sınıflandırılmasına tabi tutulmuş ve elde edilen görsel haritaya Şekil 1'de ayrıntılı olarak yer verilmiştir. Çalışma alanına yönelik yayın başlıklarında 102 ayrı sözcük toplamda 1403 defa kullanılmıştır. Packed bubbles tekniği ile hazırlanan görsel harita incelendiğinde akademisyenlerin temel çalışma alanları türlerine göre aşağıdaki şekilde bölümlendirilmiştir.

$>$ Mülki idare alanlarına göre (ülke, bölge, il, şehir, kent, köy, milli park vb.),

$>$ Turizm alt kolu uygulama alanı olarak (otel, konaklama, gastronomi, seyahat, acente, rekreasyon, yiyecek-içecek, mutfak, restoran, paket tur, kurvaziyer, yat, deniz, fuarkongre),

$>$ Gerçek kişi olarak (rehberler, ögrenci, halk, çalışan, tüketici, kadın, müşteri, yöneticiler, gezginler, personel, bayanlar, işgörenler),

$>$ Kurum/kuruluş olarak (üniversite, Unesco, IMKB, rehberler odast, il kültür ve turizm müdürlükleri),

$>$ Millet olarak (Türk, Osmanl, Asur, Yunan, Arap, Rus, Anzak)

$>$ Rehberlik alanı olarak (müze, yol, rota, bisiklet, mevzuat, antik, Helenistik),

$>$ Yayın türü olarak (proje, makaleler, lisansüstü tez, kitap) şeklinde gruplandırılabilir.

Belirtilen bu çalışma alanları içerisinde en fazla hangi değişkenin akademisyenler tarafından önemsendiği Şekil-1 üzerindeki sözcüklerin boyutları ile simgelenmiştir. 
Şekil 1. Çalışma Başlıklarında En Fazla Kullanılan Sözcükler ve Çalışmaların Uygulama Alanlar1

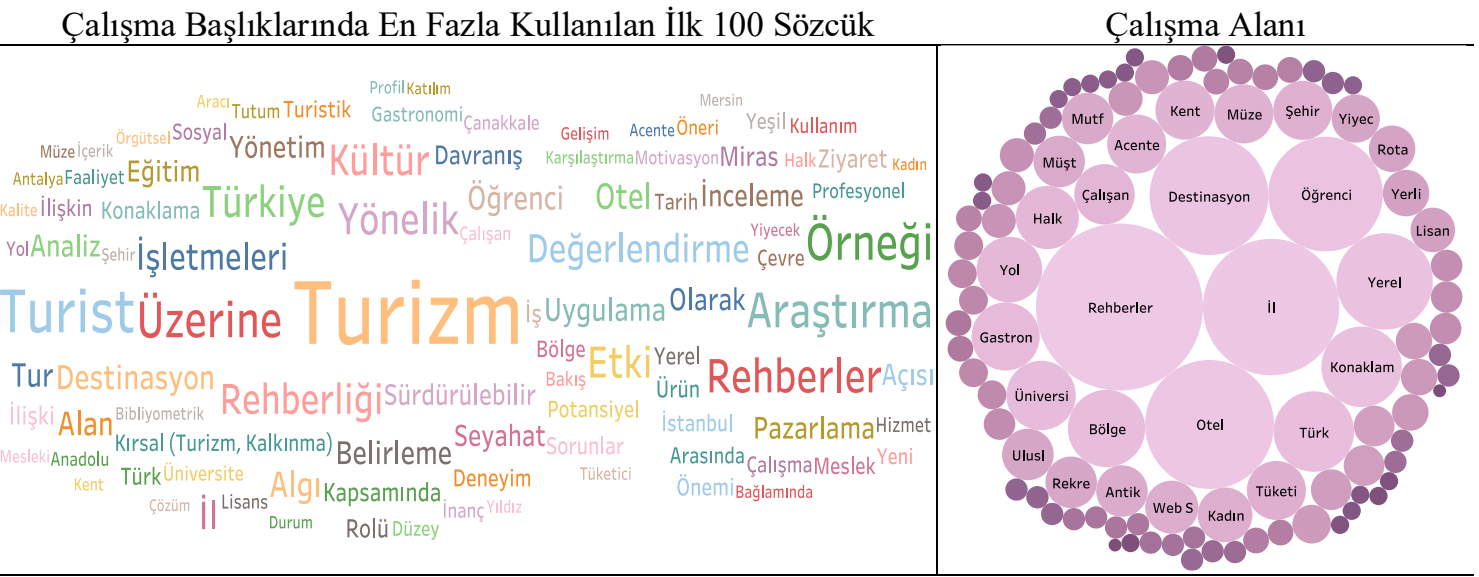

İkinci olarak yayın başlıklarında çalışmanın yapılacağı alanının bir göstergesi niteliğinde destinasyon(lar) kapsamında turizm merkezleri kendi içerisinde bir arada değerlendirilmiş ve görsel analizi yapılarak elde edilen bulgulara Şekil 2'de yer verilmiştir. Aynı il sınırları içerisinde yer alan farklı turizm merkezleri ayrı ayrı değerlendirilmiş, il ve ilçe adı olarak eş zamanlı vurgulanan destinasyonlar bir defa dikkate alınmış, tekrar eden çift sözcükler elenmiştir. Başlıklarda 68 farklı turizm merkezi/destinasyona ilişkin toplam 609 defa vurgu yapılmıştır. Destinasyonlar ayrıca packed bubbles tekniği ile görselleştirilerek en çok vurgu yapılan ilk 15 destinasyon ön plana çıkartılmıştır. $\mathrm{Bu}$ destinasyonlar incelendiğinde turist rehberi akademisyenlerin en fazla tarihi ve kültürel miras unsurları ile öne çıkan turizm merkezleri üzerinde çalışmalarını yoğunlaştırdığı söylenebilir.

Şekil 2. Çalı̧̧malarda En Fazla Uygulama Alanı Seçilen Destinasyonlar

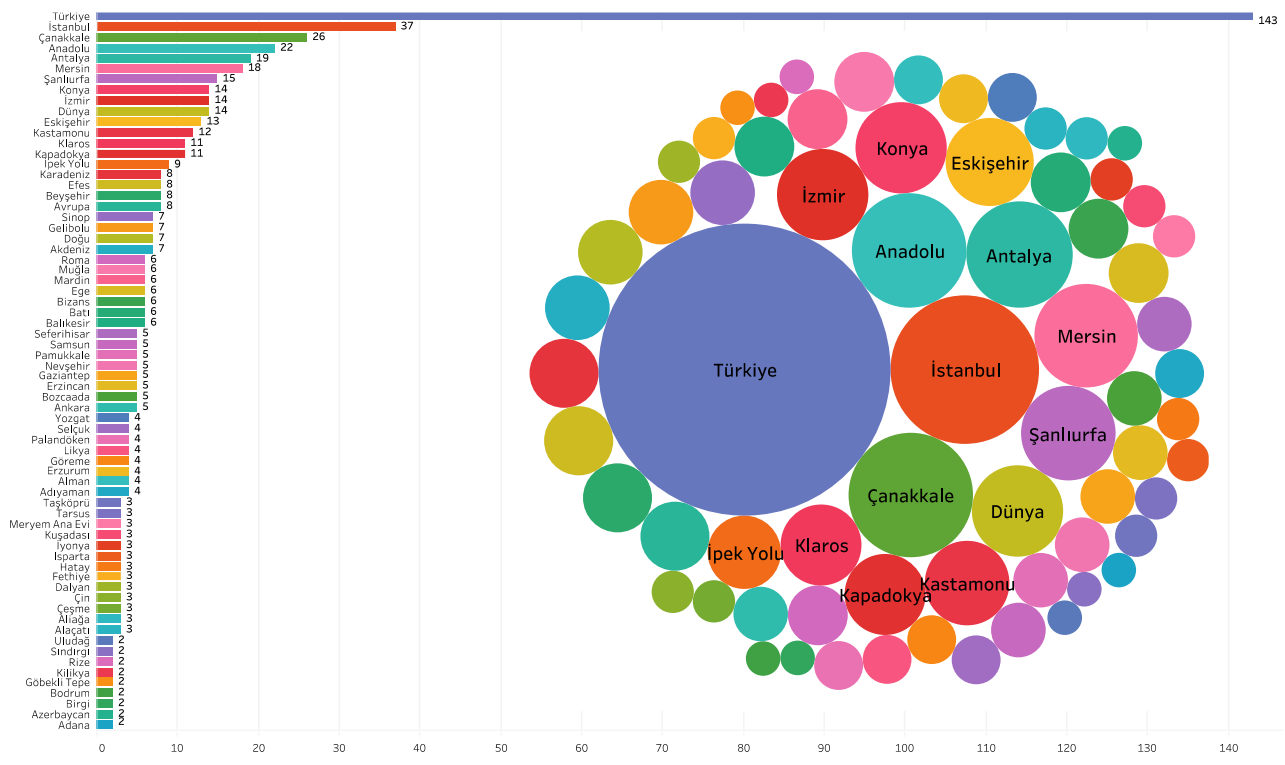

Araştırmada üçüncü olarak, çalışma yapılan konu ve alanları belirlemeye yönelik görsel analize tabi tutulmuş ve elde edilen bulgular Şekil 3'te ele alınmıştır. Bu kapsamda yönetim ve organizasyon alanında 66 sözcük 889 defa, pazarlama ile ilgili 26 sözcük 366 kere ve sürdürülebilirlik ile alakalı 17 sözcük 216 defa tekrar edilmiştir. Yönetim ve organizasyon ile ilgili en çok algı, davranış, tutum, motivasyon ve niyet sözcükleri başlıklarda yer alırken akademisyenlerin çalışma alanını oluşturan gruplar (Şekil 1) üzerinde en fazla bu 
konularda yayın yapmışlardır. Pazarlama alanında ise akademisyenlerin en fazla kullanılan sosyal medya, marka, web siteleri, imaj, rekabet gibi kavramlar ile genel pazarlama faaliyetleri ve süreçleri, tüketicilere ilişkin eğilim, tercih, beklenti, tekrar ziyaret etme niyeti gibi sözcüklerle tüketici davranışları hakkında çalışmalar yaptıkları çıkarımında bulunulabilir. Bir diğer çalışma alanı olan sürdürülebilirlik ile ilgili olarak akademisyenlerin en çok kullandığı sözcüklerin başında yeşil ve çevre kavramları gelmektedir. $\mathrm{Bu}$ kapsamda doğaya dayah/doğa temelli turizm faaliyetleri ile çevre yönetimine ilişkin kaynak, iklim, hava, su yönetimi ile çevre yönetim sistemleri üzerinde çalıştıkları görülmektedir.

Şekil 3. Çalışmaların Yoğunlaştığı Konu Alanları ile Alanlara İlişkin Kullanılan Sözcükler

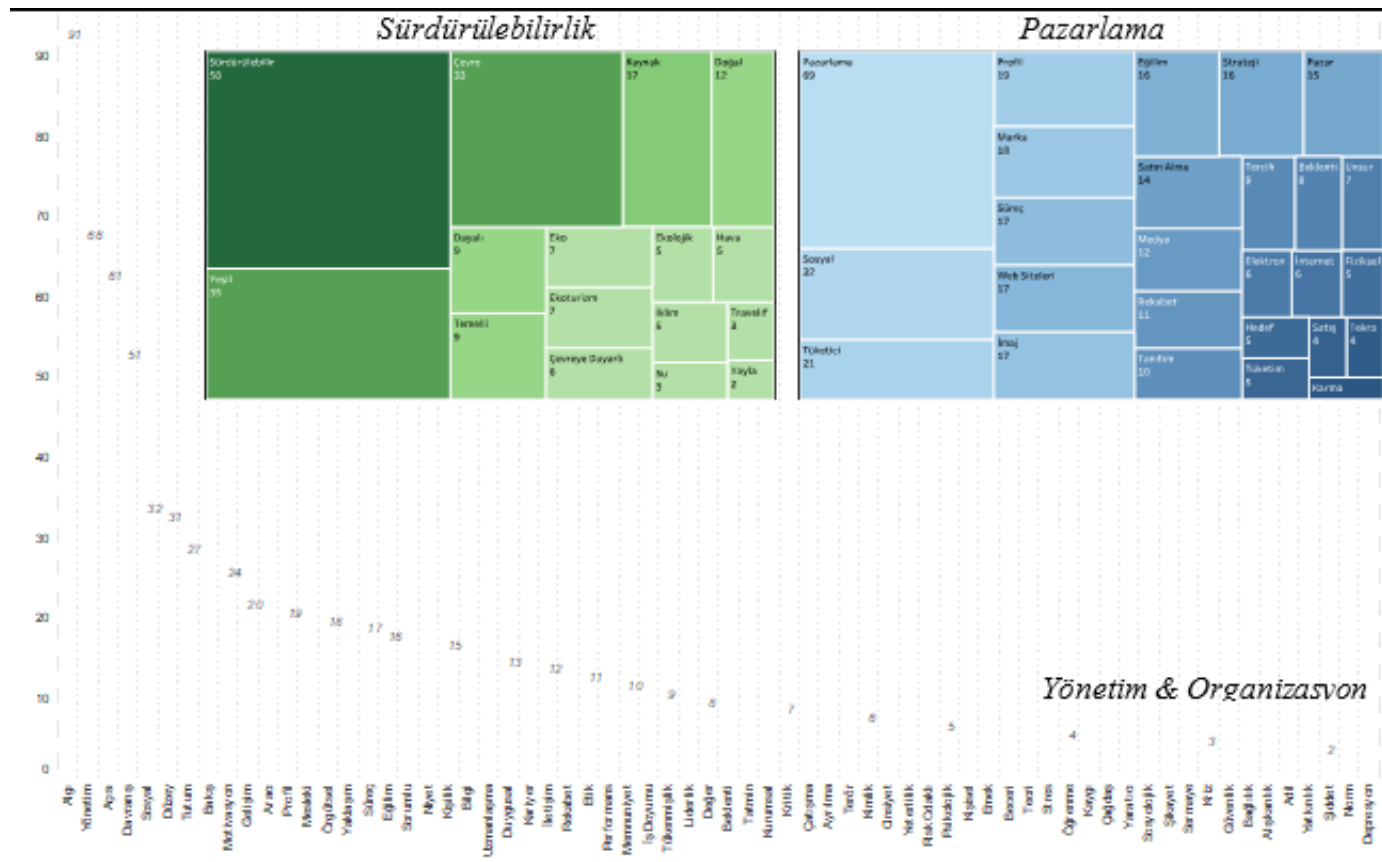

Araştırmada son olarak yayınların başlıkları “Turist Rehberliği Meslek Yönetmeliği”nin 9. maddesinde yer alan uyarınca sertifika programında okutulacak dersler ve konferanslara ilişkin konularda yer alan sözcükler doğrultusunda değerlendirmeye tabi tutularak turist rehberi akademisyenlerin çalışmalarını hangi ölçüde bu konulara paralel olarak gerçekleştirdikleri tespit edilmeye çalışılmıştır. Bu doğrultuda elde edilen bulgulara ilişkin görsel analiz haritası Şekil 4 'te paylaşılmıştır. Hazırlanan görsel haritada rehberlik ile ilgili her bir sözcüğe denk gelen konunun hem bütün içerisindeki payı text graph tekniği ile hem de konu bazında çoktan aza doğru ilgili sözcülerin niceliği shape graph tekniği ile önem düzeyine göre vurgulanmaktadır. Turist rehberi akademisyenlerin çalışmalarında rehberlikle doğrudan ilintili 52 sözcüğe ilişkin 1186 vurgu yaptığı belirlenmiştir. Tüm vurgular (8633) göz önüne alındığında akademisyenlerin \%13.7 oranında çalışmalarında doğrudan turist rehberliği ile ilgili konularda yayın yaptığı söylenebilir. 
Şekil 4: Çalışmalarda Turist Rehberliği ile İlgili Sözcüklerin Kullanımına İlişkin Bulgular

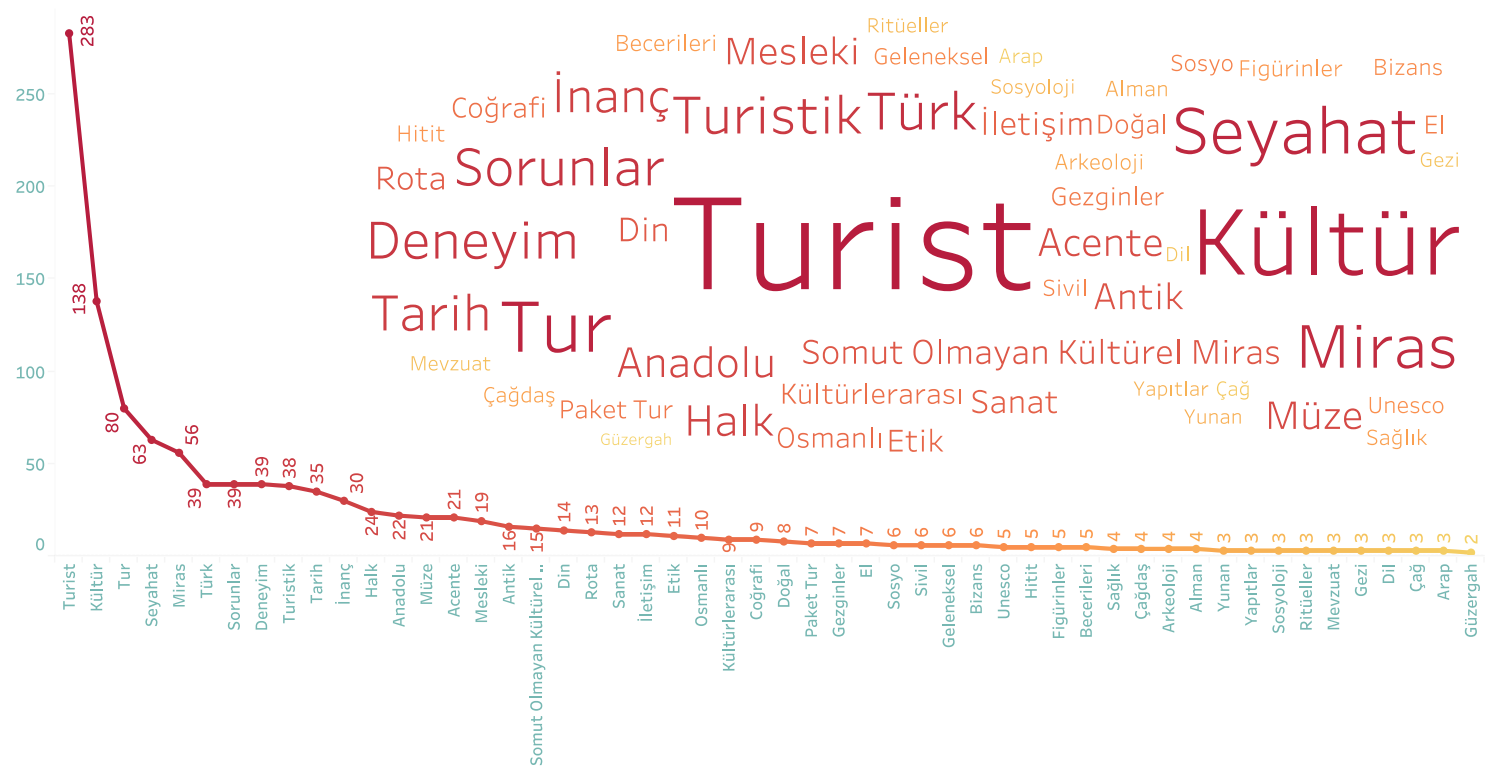

\section{TARTIŞMA, SONUÇ VE DEĞERLENDİRME}

Araştırmada turizm/turist rehberliği bölümlerinde görev yapan rehber akademisyenlerin yayınlarının veri görselleştirme tekniği ile bibliyometrik analizi gerçekleştirilmiş, çalışmada birtakım önemli sonuçlara ulaşılmıştır. İlk olarak akademisyenlerin unvanlarına göre sırasıyla en fazla doktor öğretim üyesi, araştırma görevlisi ve öğretim görevlisi olduğu belirlenmiştir. Bu sonuç, Baytok vd. (2019) ve Boyraz ve Kabakulak (2020) çalışmalarının sonuçlarıyla uyumluluk göstermektedir. Rehberlik bölümlerinde en fazla doktor öğretim üyesi unvanına sahip akademisyenlerin fazla olması rehberlik bölümlerden mezun olup doktorasını yeni bitirmiş olan akademisyenlerin fazla olmasından kaynaklanmaktadır. Ayrıca üniversitelerde kadro almak ve yükselmek çok fazla emek ve yayın gerektirdiğinden doktor öğretim üyesi olduktan sonra hem YÖK'ün hem de üniversitelerin belirlemiş oldukları farklı kriterlerden dolayı da doktor öğretim üyelerinin bir üst unvan olan doçentliğe geçişini zorlaştırması bu sonucun nedenini açıklar niteliktedir.

Akademisyenlerin eylem durumu bakımından rehberlik çalışma kartlarının 37'si aktif ve 22'si pasif iken her iki durumda da kadınların oranı erkeklerden fazladır. Çalışma kartına ekli olan dil sayıları bakımından 55 rehber akademisyenin tek bir yabancı dil bildikleri; dil türü bakımından ise başta \%88.1 ile İngilizce olmak üzere yedi farklı yabancı dile (Almanca, Bulgarca, Fransızca, Íspanyolca, Italyanca, İngilizce ve Japonca) ilişkin yetkinliklerinin olduğu belirlenmiştir. Bu sonuç Baytok vd. (2019) sonucu ile örtüşmektedir. Nitekim literatürdeki birtakım çalışmalar da bu sonucu destekler niteliktedir. Örneğin Arslan ve Şimşek (2018) kadın turist rehberlerinin yaşadıkları sorunlar üzerine yaptıkları araştırmada, mesleğin fiziki güce dayalı olması ve uzun çalışma saatlerinden kadın turist rehberlerinin yakındıklarını belirtmişlerdir. Ayrıca toplumsal ve ailevi sorunlar, iş arkadaşları ve meslektaşlarıyla yaşanan sorunlar, seyahat acenteleriyle yaşanan sorunlar, sektörün ve rehberlik mesleğin özelliğinden kaynaklanan sorunlar, müşterilerle yaşanan sorunlar, denetim ve eğitim sorunları gibi birçok sorunla karşı karşıya kaldıkları belirlenmiştir. Köroğlu, Ulusoy Yıldırım ve Kılıç (2020: 32) tarafından yapılan çalışmada ise kadın turist rehberlerinin mesleklerini icra ederken aile hayatı ile ilgili sorunlar yaşadıkları, "özellikle çocuk sahibi olan kadinlar için rehberlik biraz yorucu ve aile ile vakit geçirmeyi nispeten engelleyen bir meslek olarak algılandiğı" belirlenmiştir. Dolayısıyla mesleklerinde iş doyumsuzluğu ve olumsuz mesleki tutuma sahip kadın turist rehberlerinin varlığından söz etmek mümkündür. Bu 
durum da kadın turist rehberlerini farklı arayışlara itmektedir. Birçok kadın turist rehberi sektör tecrübelerini öğrencilere aktarmak istemekte, maaş güvencesi, toplumsal saygınlık, belirli çalışma saatleri vb. gibi birçok nedenle akademisyenliğe geçiş yapabilmekteler. Bu nedenle, bu araştırmada ortaya çıkan önemli bir sonuç olarak kadın akademisyenlerin sayısının erkeklere göre daha fazla olması, kadın akademisyenlerin daha düzenli bir hayat istemeleri, çalışma saatlerinin belli olması, düzenli gelir, sigortalı çalışma, evlenme, çocuk sahibi olma, aile ile daha fazla vakit geçirme vb. gibi durumlardan dolayı akademisyenliğe daha sıcak baktıklarına kanıt oluşturduğu söylenebilir. Turist rehberliği meslek kanununda belirtilen ana dili dışında en az bir yabancı dil bilme zorunluluğundan dolayı rehber akademisyenlerin farklı dillere haiz olmaları şaşırtıcı değildir. Çok fazla sayıda farklı dillerin rehberler tarafindan biliniyor olması, yurtdış1 yaşantılarının olması, aile bağları, coğrafi yakınlıklar, dile karşı ilgi duyma vb. nedenlerden kaynaklanıyor olabilir.

Araştırma kapsamında turist rehberi akademisyenlerin toplamda 1415 yayın ürettikleri tespit edilmiştir. Bunlar arasında en fazla yayının 626 ile bildiri (tebliğ) ve 488 ile makale türünde yapıldığı, bunu 279 kitap bölümünün ve 22 kitabın takip ettiği belirlenmiştir. Buna göre yayın dili açısından Türkçe'nin ağırlıklı olarak öne çıktığı ve ortalama her dört yayından üçünün Türkçe dilinde olduğu, yabancı dildeki yayınların \%99 ile neredeyse tamamının İngilizce dilinde yapıldığı tespit edilmiştir. Bu sonuç, Boyraz ve Kabakulak (2020)'ın çalışmasının bulgularıyla örtüşmektedir. Rehber akademisyenlerin yayınlarındaki artışın en önemli sebebi olarak sektör tecrübeli ve rehberlik bölümü mezunu kişilerin akademide istihdam edilmesiyle açıklanabilir. Yayın türü açısından rehber akademisyenlerin en fazla bildiri (tebliğ) sunmaları, araştırma görevlisi olarak istihdam edilen rehberlerin akademisyenliğe alıştırılması ve akademide tecrübe kazanmalarını sağlamaları olarak söylenebilir. Aynı şekilde makale yazmayı öğrenmek ve rehberlik mesleğine ilişkin gelişmelerin, sorunların dile getirilmesi, aynı şekilde akademik danışmanların araştırma görevlilerini makale yazmaya ve bildiri sunmaya teşvik etmeleri de yayın sayılarının artmasına katkı sunduğu söylenebilir.

Turist rehberi akademisyenlerin yayınlarının yıllara göre dağılımı incelendiğinde rehber akademisyenlerin yapmış olduğu ilk yayının 1984 yılında olduğu; takip eden 20 yıllık süreçte bilimsel yayın üretkenliklerinin çok düşük düzeyde kaldığı ve yok denecek kadar az olduğu ortaya çıkmıştır. Bu sonuç Özsoy ve Çokal'ın (2018) yapmış oldukları araştırma sonucuyla benzeşmektedir. 2005 yılı itibariyle turist rehberlerinin üniversitelerde istihdam edilme oranının artışına paralel olarak yayın sayıları da artışa geçmiş ve aynı zamanda yazar başına düşen ortalama yayın sayısı da yükselmiştir. 2016 yılında tüm zamanların en fazla yayın sayısına ulaşılmıştır. Takip eden yıllarda üniversitelerde istihdam edilen turist rehberi akademisyen sayısı artmış ve belirtilen yönetmelik çeşitli güncellemelerle yürürlükte olmasına rağmen üretilen yayınların niceliği düşüş eğilimine girdiği tespit edilmiştir.

Çalışma alanına yönelik yayın başlıklarında 102 ayrı sözcük toplamda 1403 defa kullanılmıştır. Görsel harita incelendiğinde akademisyenlerin temel çalışma alanları türlerine göre; mülki idare alanları (ülke, bölge, il, şehir, kent, köy, milli park vb.), turizm alt kolu uygulama alanı (otel, konaklama, gastronomi, seyahat, acente, rekreasyon, yiyecek-içecek, mutfak, restoran, paket tur, kurvaziyer, yat, deniz, fuar-kongre), gerçek kişi (rehberler, ögrenci, halk, çalışan, tüketici, kadın, müşteri, yöneticiler, gezginler, personel, bayanlar, işgörenler), kurum/kuruluş (üniversite, Unesco, IMKB, rehberler odasl, il kültür ve turizm müdürlükleri), millet (Türk, Osmanl, Asur, Yunan, Arap, Rus, Anzak) rehberlik alanı (müze, yol, rota, bisiklet, mevzuat, antik, Helenistik), yayın türü (proje, makaleler, lisansüstü tez, kitap) şeklinde gruplandırıldığı ortaya çıkmıştır. Bu kadar çok farklı alanlarda çalışmış olmaları rehber akademisyenlerin çok yönlü olarak yetiştirilmesi ve uzmanlaşma programlarıyla belli alanlarda uzmanlaşmaya rehberlerin teşvik edilmesiyle açıklanabilir. Bahsi geçen tüm konularda rehber akademisyenlerin turlarda az da olsa bahsi geçen her konuya değindiği ve bu konuların hemen hepsinin rehberlik mesleğinin bir parçası olduğu unutulmamalıdır. 
Turist rehberi akademisyenlerin kendilerine çalışma alanı olarak en sık seçtiği destinasyonlar incelendiğinde, araştırma başlıklarında 68 farklı turizm merkezi/destinasyona ilişkin toplam 609 defa vurgu yapıldığı tespit edilmiştir. $\mathrm{Bu}$ destinasyonlar incelendiğinde turist rehberi akademisyenlerin en fazla tarihi ve kültürel miras unsurları ile öne çıkan turizm merkezleri üzerinde çalışmalarını yoğunlaştırdığı söylenebilir. Bu kapsamda sırasıyla Türkiye (143), İstanbul (37), Çanakkale (26), Anadolu (22), Antalya (19) defa çalışmalarda vurgulanmıştır. Bu bulgu Boyraz ve Kabakulak'ın (2020) çalışmasıyla orta düzeyde benzerlik göstermektedir. Ancak her iki araştırmada da Türkiye, İstanbul ve Antalya'nın ilk beş destinasyon içinde yer alması Türkiye, İstanbul ve Antalya'nın turizm açısından önemini ortaya koymaktadır. Türkiye'nin sahip olduğu jeopolitik konum, coğrafi, iklimsel, tarihi ve kültürel özelliklerinin ne kadar önemli olduğunu göstermektedir. Ayrıca Dünya'da en fazla turist çeken ilk 10 ülke arasında olması da araştırmalarda sıkça vurgulanmasının nedenini açıklamaktadır. Ayrıca Türkiye'nin iki önemli turizm destinasyonu olan İstanbul ve Antalya ağırladıkları turist sayısının fazla olması, alt yap1 ve üst yapı bakımından gelişmiş destinasyonlar oldukları, ayrıca İstanbul'un 2010 yılında Avrupa Kültür Başkenti seçilmesi turist rehberi akademisyenlerin ilgisini bu merkezlere çekmiştir. İstanbul Kültür Başkenti olarak yapması gerekenler, turistlere hizmet sunabilecek yatak kapasitesi, alt yapı ve üst yapı eksiklikleri, yerel halkın ve hükümetin bu organizasyonlara bakış açis1 vb. birçok konunun gündeme getirilmesi ve varsa bu konularda eksikliklerin giderilmesi ve politikalar geliştirilmesine katkıda bulunulması açısından kültür ve tanıtım elçileri olan turist rehberi akademisyenlerin çalışmalarında en çok vurgulanan destinasyonlar olmasına dair bir fikir verebilir. Antalya için de durum benzerdir. Turizm başkenti olması, turizm açısından ve turist sayısı açısından göz bebeği konumunda olan Antalya'nın markalaşması, verilen hizmetlerin kalitesinin arttırılması, turistlerin görüş ve önerilerinin alınması ve bu görüşlere istinaden iyileştirilmelerin yapılması, destinasyonun fiziksel, sosyal taşıma kapasitesinin ölçülmesi vb. konularda yerel yetkililere ve diğer ilgililere fikir vermesi açısından rehber akademisyenlerin Antalya' $y$ ı çalışma olarak seçmesinde önemli etkenler olarak değerlendirilebilir. Aynı zamanda hem İstanbul hem de Antalya'nın ulaşım araçlarıyla (havayolu, karayolu, demiryolu) kolayca ulaşılabilecek noktalarda olması; turist rehberi odalarının bulunması ve en fazla turist rehberi üye sayısına sahip odalar (TUREB, 2020) olmalarından dolayı da İstanbul ve Antalya'yı diğer destinasyonlar içinde öne çıkardığı ifade edilebilir.

Turist rehberi akademisyenlerin çalışmalarını en fazla yoğunlaştırdıkları konular ve alanlar incelendiğinde, yönetim ve organizasyon alanında 66 sözcük 889 defa, pazarlama ile ilgili 26 sözcük 366 kere ve sürdürülebilirlik ile alakalı 17 sözcük 216 defa tekrar edildiği belirlenmiştir. Yönetim ve organizasyon ile ilgili en çok algı, davranış, tutum, motivasyon ve niyet sözcükleri başlıklarda yer alırken akademisyenlerin çalışma alanını oluşturan gruplar üzerinde en fazla bu konularda yayın yapmışlardır. Pazarlama alanında ise akademisyenlerin en fazla kullanılan sosyal medya, marka, web siteleri, imaj, rekabet gibi kavramlar ile genel pazarlama faaliyetleri ve süreçleri, tüketicilere ilişkin eğilim, tercih, beklenti, tekrar ziyaret etme niyeti gibi sözcüklerle tüketici davranışları hakkında çalışmalar yaptıkları çıkarımında bulunulabilir. Bir diğer çalışma alanı olan sürdürülebilirlik ile ilgili olarak akademisyenlerin en çok kullandığı sözcüklerin başında yeşil ve çevre kavramları gelmektedir. Bu kapsamda doğaya dayalı/doğa temelli turizm faaliyetleri ile çevre yönetimine ilişkin kaynak, iklim, hava, su yönetimi ile çevre yönetim sistemleri üzerinde çalıştıkları görülmektedir. Boyraz ve Kabakulak (2020) tarafindan hazırlanmakta olan tezlere yönelik yapılan araştırmada da benzer sonuçlara ulaşılmıştır. $\mathrm{Bu}$ sonuçlar incelendiğinde rehber akademisyenlerin aslında yüksek lisanstan itibaren çalıştıkları danışman öğretim üyelerinin temel çalışma alanlarının da pazarlama veya yönetim olmasından dolayı özellikle bu iki alandan birinde devam etme durumunda kalmaktadırlar. Böylelikle rehber akademisyenler doktoralarını bitirdikten sonra da genel olarak danışman öğretim üyelerinin izinden giderek pazarlama ya da yönetim alanında rehberlik mesleğine uygun çalışmalar gerçekleştirdikleri söylenebilir. 
Araştırmada son olarak yayınların başlıkları “Turist Rehberliği Meslek Yönetmeliği”"nin 9. maddesinde yer alan uyarınca sertifika programında okutulacak dersler ve konferanslara ilişkin konularda yer alan sözcükler doğrultusunda değerlendirmeye tabi tutularak turist rehberi akademisyenlerin çalışmalarını hangi ölçüde bu konulara paralel olarak gerçekleştirdikleri tespit edilmeye çalışılmıştır. Turist rehberi akademisyenlerin çalışmalarında rehberlikle doğrudan ilintili 52 sözcüğe ilişkin 1186 vurgu yaptığı belirlenmiştir. Tüm vurgular (8633) göz önüne alındığında akademisyenlerin \%13.7 oranında çalışmalarında doğrudan turist rehberliği ile ilgili konularda yayın yaptığı söylenebilir. Nitekim Çapar ve arkadaşlarının (2018) turizm rehberliği alanında yazılan ulusal makalelerde sık kullanılan anahtar sözcükleri inceledikleri çalışmada en sık kullanılan anahtar sözcükler olarak "turizm, turist, eğitim, meslek, hizmet"in ön plana çıkması da olduğu ve bu çalışmada ulaşılan sonuçları destekler niteliktedir.

Araştırma kapsamında ulaşılan önemli kazanımlara karşın bir takım temel sınırlılıklar da bulunmaktadır. İlk olarak, araştırmada lisans ve önlisans düzeyindeki sadece turizm ve turizm rehberliği bölümlerinde görev yapan turist rehberi akademisyenlerin yayınlarını kapsarken turizm dışındaki alanlarda görev yapan çalışma kartına sahip akademisyenlerin yayınları dikkate alınmamıştır . İkincisi, veri toplama kanalı olarak YÖK Akademik Veri Tabanı ve üniversitelerin web siteleri ile sınırlandırılmış, bu mecraların dışında akademik personele yönelik bilgi içerebilecek alanlar kapsam dışında yer almıştır. Son olarak, araştırma sonuçları Şubat 2020 itibariyle geçerli olup verilerin toplanma sürecinde ilgili veri tabanındaki akademisyenlere ilişkin yer verilmiş bilgiler ile sınırlıdır, veri tabanında yer almasına rağmen henüz sisteme veri girişi yapmamış veya herhangi bir yayın üretmemiş olan turist rehberi akademisyenler kapsam dışı tutulmuştur. Bu kapsamda elde edilen verilerin/bilgilerin sınırlı olması nedeniyle çalışmada ele alınabilecek değişkenler ile bunlara yönelik gerçekleştirilen görsel analizler de bu sınırlar doğrultusunda değerlendirilebilmiştir. Dolayısıyla konu ile ilgili olarak ilerleyen dönemde gerçekleştirilecek çalışmalarda bu sinırlılıkların dikkate alınmalı ve mevcut araştırmanın sonuçları da bu sınırlılıklar kapsamında değerlendirilmelidir.

\section{KAYNAKÇA}

Arslan, A. \& Şimşek, G. (2018). Kadın Turist Rehberlerinin Yaşadıkları Mesleki Sorunlar: Aydın Turist Rehberleri Örneği. Journal of Travel and Tourism Research, 13, 23-49.

Arslantürk, Y., Küçükergin, F. N. \& Apalı, Z. (2016). Turist Rehberliği Eğitiminde Güncel Durum ve Kavram Karmaşası. 17. Ulusal Turizm Kongresi, 20-23 Ekim, Muğla-Bodrum, 915-922.

Aylan, S. \& Başoda A. (2018). Türkiye'de Turist Rehberliği Lisans Programlarındaki Akademik Personel Istihdamının Değerlendirilmesi. N. Hacıoğlu, C. Avcıkurt, A. Kılıç, H. Ulusoy Yıldırım (Ed.), Turist Rehberliği Üzerine Güncel Araştırmalar, Ankara: Detay Yayıncılık, 132-154.

Baytok, A., Boyraz, M. \& Kabakulak, A. (2019). Turizm/Turist Rehberliği Bölümü Akademisyenlerinin Profili: Türkiye Üniversiteleri Örneği, Uluslararası Sosyal Araştırmalar Dergisi, 12 (68), 10381049.

Black, R., Weiler, B. \& Chen, H. (2018). Exploring Theoretical Engagement in empirical Tour Guiding Research and Scholarship 1980-2016: A Critical Review, Scandinavian Journal of Hospitality and Tourism, 19(1), 95-113.

Boyraz, M. \& Kabakulak, A. (2020). Türkiye'deki Turizm Rehberliği Bölümlerinde Görev Yapan Akademisyenlerin Bilimsel Yayınlarının Bibliyometrik Analizi, Türk Turizm Araş̧ırmaları Dergisi, 4(3), 2152-2163.

Boyraz, M., Kabakulak, A. \& Mutlu, A. S. (2020). Hazırlanmakta Olan Turizm Konulu Lisansüstü Tezlerin Veri Görselleştirme Tekniği İle Bibliyometrik Analizi: 2006-2020 Yılları Örneği, Türk Turizm Araştırmaları Dergisi, 4(2), 1434-1453.

Çapar, G., Toksöz, D. \& Dönmez, B. (2018). 2005-2017 Yılları Arasında Dünya'da ve Türkiye'de Turizm Rehberliğinin Gelişimi. N. Hacıoğlu, C. Avcıkurt, A. Kılıç, H. Ulusoy Yıldırım (Ed.), Turist Rehberliği Üzerine Güncel Araştırmalar, Ankara: Detay Yayıncılık, 1-16. 
Doğancılı, O. S. \& Karaçar, E. (2018). Turizm Rehberliği Bölümünde Bulunan Akademisyenlerin YÖK Akademik Profillerinin İncelenmesi. (Editör) Çobanoğlu, Y.: Sosyal, Beşeri ve İdari Bilimler Alanında Akademik Çalışmalar (Cilt I, ss. 83-94). Ankara: Gece Kitaplığı.

Gülcan, B. (2011). Turizmde Doçentlik Unvanı: Kapalı Kariyer Yolu ve Etkileri. İşletme Araştırmaları Dergisi, 3(1), 3-32.

Günay, D. \& Günay, A. (2011). 1933'den Günümüze Türk Yükseköğretiminde Niceliksel Gelişmeler. Yüksekögretim ve Bilim Dergisi, 1(1), 1-22.

Hall, C. M. (2011). Publish and Perish? Bibliometric Analysis. Journal Ranking and the Assessment of Research Quality in Tourism, Tourism Management, 32(1), 16-27.

İRO, (2020). Tura Çıkarken. https://iro.org.tr/tr/212-page-tezsiz-yuksek-lisans-programi-ve-rehberlikegitimi-uzerine-kamuoyuaciklamasidir.aspx, (Erişim Tarihi: 26.09.2020).

İşçeli, Z. \& Kılıç, G. (2018). Lisans Düzeyinde Turizm Eğitimi Veren Fakültelerin Müfredatlarının İncelenmesi. Turist Rehberliği Dergisi, 1(1), 41-56.

Karataş, T., Özen, Ş. \& Gülnar, E. (2017). Akademisyenlerin Kariyer Basamakları ve Yükseltme Ölçütlerine İlişkin Görüşleri. Yükseköğretim Dergisi, 7(2), 82-93.

Kaygalak, S. Ç. \& Kırlar, B. C. (2019). Turizm Rehberliği Alanında Yapılan Makalelerin Bibliyometrik Analizi. International Journal of Contemporary Tourism Research, 3(2), 213-223.

Köroğlu, Ö, Ulusoy Yıldırım, H. ve Kılıç, A. (2020). Kadın Turist Rehberlerinin Mesleki Sorunlarının Belirlenmesi. Mehmet Akif Ersoy Üniversitesi Sosyal Bilimler Enstitüsü Dergisi, (31), 26-40. DOI: $10.20875 /$ makusobed.586054.

Özsoy, A. \& Çokal, Z. (2018). Türkiye’de Turist Rehberliği Alanında Yayımlanmış Lisansüstü Tezlerin Bibliyometrik Analizi (1989-2018). 2nd International EMI Entrepreneurship \& Social Sciences Congress, 09-11 November 2018, Cappadocia.

Pelit, E. \& Katırcıoğlu, E. (2018). Turist Rehberliği Mesleğinde Taraflar Açısından Yaşanan Sorunlar Üzerine Bir Değerlendirme. Turist Rehberliği Dergisi, 1(2), 74-94. DOI: 10.34090/tured.486198.

Polat, T. (2001). Seyahat İsletmelerinde Profesyonel Turist Rehberliği, Rehberlik Mesleğinin Sorunları ve Çözüm Önerileri Üzerine Bir Alan Araştırması. Yayınlanmamış Yüksek Lisans Tezi. Eskişehir Anadolu Üniversitesi Sosyal Bilimler Enstitüsü.

Resmi Gazete, (2019). Turist rehberliği meslek kanunu. http://www.resmigazete.gov.tr/eskiler/2012/06/20120622-2.htm, (Erişim Tarihi: 26.09.2020).

Şahin, S. \& Acun, A. (2015). Turist Rehberliği Alanının Bibliyometrik Profili (Ulusal Turizm Kongreleri Bildirileri). Balıkesir Üniversitesi Sosyal Bilimler Enstitüsü Dergisi, 18(34), 213-234.

TUADER, Turizm akademisyeni kimdir?, (2020) https://tuader.org (Erişim Tarihi: 25.10.2020).

Tureb, Mevzuat, Yönetmelik, (2020). http://www.tureb.org.tr/tr/Page/Detail/62. (Erişim Tarihi: 25.10.2020).

TUREB, Raporlar, Rehber Istatistikleri, (2020). http://tureb.org.tr/tr/RehberIstatistik/. (Erişim Tarihi: 14.10.2020).

YÖK, Yükseköğretim Bilgi Yönetim Sistemi, (2020). https://istatistik.yok.gov.tr/, (Erişim Tarihi: 26.09.2020). 